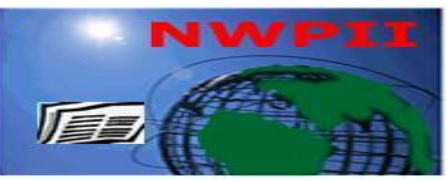

American Journal of Biomedical Sciences

ISSN: 1937-9080

nwpii.com/ajbms

\title{
Evaluation of Antitumor Activity of Leea indica (Burm.f.) Merr. extract against Ehrlich Ascites Carcinoma (EAC) Bearing Mice
}

\author{
Md. Obayed Raihan ${ }^{1 *}$, Syed Mohammed Tareq ${ }^{1}$, Afrina Brishti ${ }^{2}$, Md. Kursad Alam², Anamul Haque ${ }^{3}$, \\ Md.Sekendar $\mathrm{Ali}^{1}$
}

${ }^{1}$ Department of Pharmacy, International Islamic University Chittagong, Chittagong, Bangladesh

${ }^{2}$ Department of Pharmacy, University of Rajshahi, Rajshahi, Bangladesh

${ }^{2}$ Department of Pharmacy, International Islamic University Chittagong, Chittagong, Bangladesh

${ }^{3}$ Department of Pharmacy, Brac University, Mohakhali, Dhaka, Bangladesh

"Corresponding Author:

Md.Obayed Raihan

Lecturer

Department of Pharmacy

International Islamic University Chittagong (IIUC)

Chittagong-4203, Bangladesh

TEL +88-031-610085, 638656-7, 610308, Ext-160

Cell: $+88-01716-664747$

FAX +88-031-610307

E-mail: ronipharm2000@yahoo.com

Received: 19 December 2011; $\mid$ Revised: 31 December 2011; | Accepted: 18 January 2012

\begin{abstract}
Most of the conventional anti tumor drugs are designed to have selective toxicity to rapidly dividing cells. Among these agents the focus of many studies are compounds obtained from natural products that significantly reduce tumor size and enhance the survival time. In this study the crude methanolic extract of the leaves of Leea indica (L. indica) was examined for their anti tumor, anti-oxidant and cytotoxic activity. In vivo anti tumor activity was studied against Ehrlich Ascites Carcinoma (EAC) cells in Swiss albino mice by monitoring parameters like tumor weight measurement, survival time and tumor cell growth inhibition. It has been found that the compound at the dose of $40 \mathrm{mg} / \mathrm{kg} /$ day (i.p) significantly decreases tumor weight, increases life span and reduces tumor cell growth rate in comparison to those of EAC bearing mice receiving no extract. Bleomycin was used as a positive control $(0.3 \mathrm{mg} / \mathrm{kg})$. In vitro anti-oxidant potentiality was tested using DPPH radical scavenging test, total phenol and flavonoid content and reducing power determination assays. The extracts showed moderate antioxidant activity in a dose dependent manner. The cytotoxic activity of the extract was assessed by brine shrimp lethality bioassay technique which showed significant result $\left(\mathrm{LC}_{50}\right.$ less than $\left.25 \mu \mathrm{g} / \mathrm{ml}\right)$. Anti tumor properties of L.indica could be linked with the presence of these antioxidant and cytotoxic activity. These outcomes indicate the possible potential use of L.indica as anti tumor agent.
\end{abstract}

Keywords: Antitumor activity, EAC cell, antioxidant, cytotoxicity, Leea indica. 


\section{Introduction}

After cardiovascular diseases, cancer is the second major cause of death in the western world accounting for $24 \%$ of all deaths. In European countries each year over three quarters of a million people die from cancer [1]. Bangladesh has an immense wealth of medicinal plant species, both endemic and non-endemic. The most extensive screening for anticancer compounds obtained from plant species was done by National Cancer Institute (NCI) in the USA. More than 35,000 species (or about $14 \%$ of the estimated number of higher plant species on earth) collected from different rain forests in Asia, Africa and the Amazon were screened by the NCI alone [2]. Many natural plant extracts and phytochemicals have been reported to induce apoptosis in cancer cell lines [3-5]. From the screening process, taxol from Taxas brevifolia was discovered and developed into one of the most successful plant based anti cancer drug. Other anticancer drugs originated from plants include vinblastine and vincristine derived from Catharatus roseus and etoposide from Podophyllum peltatum, to name a few. Although chemotherapy is effective in detecting cancer at a very early stage, the side effects and resistance towards drug are a major problem. Hence new drugs or treatments are needed. Identification of new cytotoxic compounds led the development of anticancer therapeutics for several decades. The induction of apoptosis with cytotoxic compound is known to be an efficient and promising strategy to kill cancer cells [6]. Compounds of natural origin have often provided new leads in the novelty of structures with anticancer activity. In the present study, Leea indica was selected for the evaluation of its anti tumor potential against EAC cell line.

Leea indica (Burm.f.) Merr. (Family Leeaceae) is an evergreen perennial shrub with stout, soft wooded, glabrous stems indigenous to tropical Asia, Australasia, Pacific and grown mostly in Bangladesh, India, China, Bhutan and Malaysia. The leaves are claimed to have some medicinal values such as anticancer, antidiabetic, antidiarrhoeal, antidysenteric and antispasmodic based on local uses [7-9]. The ointment prepared from roasted leaves relieves vertigo [10]. The whole plant is used traditionally for headache, body pains and skin complaints [7, 8]. Marma tribes of Chittagong Hill Tracts, Bangladesh, prescribe combined root paste of this plant along with the root of Oreocnide integrifolia and Cissus repens in bubo and boils [11]. Previous biological studies have shown that it possesses strong antioxidant [12], CNS depression [13], phosphodiesterase and nitric oxide synthase inhibitory activities [14]. Apart from the initial screening against breast cancer cell line [15] and Ca Ski Human Cervical Epidermoid Carcinoma Cell line [16] still there is no report showing the anti tumor activity of L.indica against EAC cell lines. Moreover, no detailed mechanism of action underlying the anti tumor activity of L.indica had been delineated.

\section{Materials and Methods}

\subsection{Drugs and chemicals}

All the chemicals and reagents used throughout the investigation were of reagent grade. DPPH (1, 1-diphenyl, 2-picrylhydrazyl), Methanol and DMSO (dimethyl sulfooxide) were purchased from Sigma Chemical Co. USA, Ascorbic acid and Gallic acid were from SD Fine Chem. Ltd. India.

\subsection{Plant material}

The plant leaves were collected from the hill forest of Chittagong district in November 2010 when leaves were in their maximum densities. The plant parts were thoroughly washed with water and were dried in hot air oven at room temperature for 7 days and at $40^{\circ} \mathrm{C}$ for the next 2 days.

\subsection{Preparation of plant Extract}

The dried leaves were coarsely powdered and about $1000 \mathrm{~g}$ of powdered material was macerated with $99 \%$ methanol at room temperature for a period of 7 days accompanying occasional shaking and stirring. The whole mixture was then filtered and the filtrate thus obtained was concentrated by using a rotary evaporator (Bibby RE200, Sterlin Ltd, UK) to get a viscous mass. The viscous mass was then kept at room temperature under a ceiling fan to get a dried extract (about 10\% of the whole mass). Sample for antitumor assay was prepared 
by dissolving the dried methanolic extract in $0.2 \%$ DMSO. From this solution, different working dilutions were prepared to get concentration range for $20,30,40 \mathrm{mg} / \mathrm{kg}$ doses. The standard drug bleomycin was also dissolved in same solvent to make dose of $0.3 \mathrm{mg} / \mathrm{kg}$ body weight.

\subsection{Animals}

White albino male mice (Swiss-webstar strain, 20-25 g body weight) were collected from the animal research branch of the International Center for Diarrheal Disease and Research, Bangladesh (ICDDRB). The animals were provided with standard laboratory food and tap water ad libitum and maintained at natural day night cycle. The animals were acclimatized to laboratory condition for one week prior to experimentation.

\subsection{Tumor cells}

Ehrlich Ascites Carcinoma (EAC) cells were obtained by the Department of Biochemistry and Molecular Biology, University of Rajshahi, Rajshahi-6205, Bangladesh and were maintained by weekly intraperitoneal (i.p.) inoculation of $10^{5}$ cells/mouse in the laboratory.

\subsection{Ethical clearance}

Protocol used in this study for the use of mice as animal model for cancer research was approved by the Rajshahi University Animal Ethical committee (27/08/RUBCMB).

This research work was approved by Ethical Review Committee of Research cell of Rajshahi Medical College, Bangladesh (ref. RMC/ER/20102013/01).

\subsection{Determination of median lethal dose $\left(\mathbf{L D}_{50}\right)$}

The $\mathrm{LD}_{50}$ value was determined following conventional methods [17]. The test compound was dissolved in distilled water and injected intraperitoneally to six groups of mice (each containing 5 mice) at different doses (20, 50, 100, 200, 250 and $400 \mathrm{mg} / \mathrm{kg}$ ). LD 50 was evaluated by recording mortality after 24 hours.

\subsection{Evaluation of Anticancer potentiality}

Anticancer potentiality of methanol extract of the aerial parts of L.indica was evaluated by measuring tumor cell growth inhibition, regression of tumor size and increase of survival time.

\subsection{Cell growth inhibition}

In vivo tumor cell growth inhibition was carried out by the method as described by Sur et al. [18]. For this study, 5 groups of mice (5 in each group) were used. For therapeutic evaluation 14 $\times 10^{5}$ cells/mouse were inoculated into each group of mice on the first day. Treatment was started after 24 hours of tumor inoculation and continued for 5 days. Group 1 to 3 received the test compound at the doses of $20 \mathrm{mg} / \mathrm{kg}$ (i.p.), 30 $\mathrm{mg} / \mathrm{kg}$ (i.p.) and $40 \mathrm{mg} / \mathrm{kg}$ (i.p.) respectively per day per mouse. In each case the volume of the test solution injected (i.p.) were $0.1 \mathrm{ml} /$ day per mouse. Group 4 received bleomycin $(0.3 \mathrm{mg} / \mathrm{kg}$, i.p. $)$ and finally group 5 was treated with the vehicle (normal saline) and was considered as untreated control. The mice were sacrificed on the 6th day after transplantation and tumor cells were collected by repeated intraperitoneal wash with $0.9 \%$ saline. Viable tumor cells per mouse of the treated group were compared with those of control.

The cell growth inhibition was calculated by using the formula,

$$
\% \text { Cell growth inhibition }=\left(1-\frac{\mathrm{TW}}{\mathrm{CW}}\right) \times 100
$$

Where, $\mathrm{Tw}=$ Mean of number of tumor cells of the treated group of mice and

$\mathrm{Cw}=$ Mean of number of tumor cells of the control group of mice.

\subsection{Average tumor weight and survival time}

These parameters were measured under similar experimental conditions as stated in the previous experiment. Tumor growth was monitored daily by measuring weight change. The host survival time was recorded and expressed as mean survival time in days and percent increase of life span was calculated [19] as follows:

Mean survival time $(\mathrm{MST})=$

$\underline{\sum S u r v i v a l ~ t i m e ~ i n ~ d a y s ~ o f ~ e a c h ~ m o u s e ~ g r o u p ~}$ Total number 
Percent increase of life span (ILS) $\%=$

$$
\left(\frac{\text { MST of treated group }}{\text { MST of control group }}-1\right) \times 100
$$

\subsection{Antioxidant capacity determination}

Antioxidant potentiality of methanol extract of the leaves of L.indica was evaluated by determining DPPH radical scavenging activity, total phenol and flavonoid content determination and reducing capacity assays.

$D P P H$ radical scavenging activity: The free radical scavenging capacity of the extracts was determined using DPPH $[20,21]$. A methanolic solution of DPPH $(0.004 \%$ w/v) was mixed with solutions of different concentrations (0 to $500 \mu \mathrm{g})$ of L.indica extracts and after 10 minutes the absorbance was read at $515 \mathrm{~nm}$ using a spectrophotometer (Shimadzu UVmini-1240, Japan). Ascorbic acid was used as a standard. The inhibition curve was plotted and $\mathrm{IC}_{50}$ values were calculated.

Determination of total phenolic content: The total phenolic content of extracts was determined using Folin-Ciocalteu method [22]. The extracts were oxidized with Folin-Ciocalteu reagent and were neutralized with sodium carbonate. The absorbance of the resulting blue color solution was measured at $760 \mathrm{~nm}$ after $60 \mathrm{~min}$ using Gallic acid (GA) as standard. Total phenolic content was expressed as mg GA equivalent/gm of extract.

Determination of total flavonoid content: The flavonoid content was determined using a method described by Kumaran and Karunakaran [23] using quercetin as a reference compound. $1 \mathrm{mg}$ of plant extract in methanol was mixed with $1 \mathrm{ml}$ aluminium trichloride in Ethanol $(20 \mathrm{mg} / \mathrm{ml})$ and a drop of acetic acid, and then diluted with Ethanol. The absorption at $415 \mathrm{~nm}$ was read after 40 minute. The absorptions of blank samples and standard quercetin solution $(0.5 \mathrm{mg} / \mathrm{ml})$ in methanol were measured under the same conditions.

Reducing power: The reducing power activity of L.indica extract was determined according to the method described by Oyaizu [24]. Different concentrations of methanol extract of the leaves of L.indica in $1 \mathrm{ml}$ of distilled water was mixed with phosphate buffer $(2.5 \mathrm{ml}, 0.2 \mathrm{M}, \mathrm{pH} 6.6)$ and potassium ferricyanide $\left[\mathrm{K}_{3} \mathrm{Fe}(\mathrm{CN})_{6}\right](2.5 \mathrm{ml}, 1 \%)$. The mixture was incubated at $50^{\circ} \mathrm{C}$ for $20 \mathrm{~min}$. A portion $(2.5 \mathrm{ml})$ of trichloroacetic acid $(10 \%)$ was added to the mixture, which was then centrifuged at 3,000rpm for $10 \mathrm{~min}$. The upper layer of the solution $(2.5 \mathrm{ml})$ was mixed with distilled water $(2.5 \mathrm{ml})$ and $\mathrm{FeCl}_{3}(0.5 \mathrm{ml}, 0.1 \%)$ and the absorbance was measured at $700 \mathrm{~nm}$. Ascorbic acid was used as a reference standard. Phosphate buffer was used as blank solution.

\subsection{Brine shrimp lethality bioassay (cytotoxicity)}

Brine shrimp lethality bioassay was carried out to investigate the cytoxicity of plant extracts [25]. 50mg of Artemia salina (Leach) eggs were added to a hatching chamber containing sea water (75ml). The hatching chamber was kept under an inflorescent bulb for 48 hours for the eggs to hatch into shrimp larvae. The matured nauplii were then used in the experiment. For the experiment $3 \mathrm{mg}$ of the compound was dissolved in $0.6 \mathrm{~mL}(600 \mu \mathrm{L})$ of distilled water to get a concentration of $5 \mu \mathrm{g} / \mu \mathrm{L}$ and by serial dilution technique, solutions of varying concentrations such as $5,10,20,40,80$ and $100.0 \mu \mathrm{g} / \mathrm{ml}$ were obtained. After 24 hours of incubation, the vials were observed using a magnifying glass and the number of surviving nauplii in each vial were counted and noted. From this data, the percentage of mortality of the nauplii was calculated for each concentration and the $\mathrm{LC}_{50}$ value was determined using Probit analysis as described in the literature [26].

\subsection{Statistical analysis}

In all the experiments, data were expressed as means \pm standard error of mean. A significant difference from the respective control for each experiment was assessed by using one way ANOVA followed by Dunnett ' $\mathrm{t}$ ' test with $P$ values $<0.05$ being regarded as statistically significant.

\section{Result}

\subsection{Median Lethal Dose $\left(\mathbf{L D}_{\mathbf{5 0}}\right)$}

No mortality was noticed up to $250 \mathrm{mg} / \mathrm{kg}$ body weight (i.p.), whereas, $100 \%$ mortality was noticed at the dose of $400 \mathrm{mg} / \mathrm{kg}$ (i.p.). The $\mathrm{LD}_{50}$ 
of the extracts was found to be $300 \mathrm{mg} / \mathrm{kg}$ body weight (i.p.). One-tenth of this dose was selected as the therapeutic dose [27] for the evaluation of anti tumor activity.

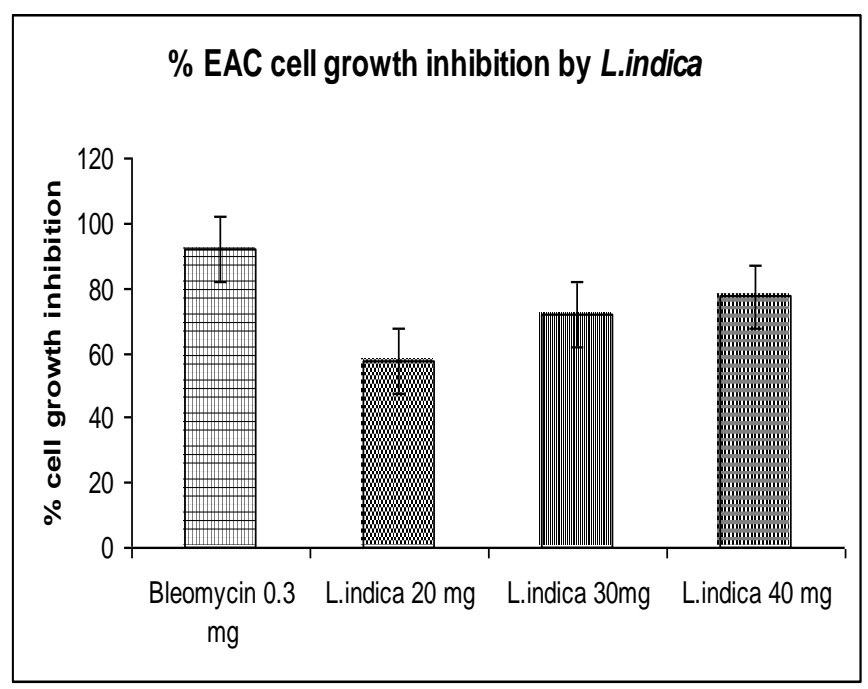

Figure 1. Effect of methanol extract of the leaves of L.indica on \%EAC cell growth inhibition (In vivo). Values are mean $\pm \mathrm{SEM},(n=5)$; where significant value is $* * p<0.001$, Dunnet test as compared to control.

\subsection{Cell growth inhibition}

The effects of the different doses of methanol extract of the leaves of L.indica at the dose of 20 $\mathrm{mg} / \mathrm{kg}$ (i.p), $30 \mathrm{mg} / \mathrm{kg}$ (i.p), and $40 \mathrm{mg} / \mathrm{kg}$ (i.p) and bleomycin at $0.3 \mathrm{mg} / \mathrm{kg}$ (i.p) per mouse per day on EAC cell growth inhibition (In vivo) was observed. Among the three doses tested, the methanol extract at the dose of $40 \mathrm{mg} / \mathrm{kg}$ body weight showed maximum antitumor activity with $77.29 \%$ inhibition of cell growth. This activity was comparable to that of standard drug bleomycin, which showed $92.02 \%$ cell growth inhibition when administered similarly at a dose of $0.3 \mathrm{mg} / \mathrm{kg}$ (i.p). Whereas the same extract at the dose of $20 \mathrm{mg} / \mathrm{kg}$ and $30 \mathrm{mg} / \mathrm{kg}$ body weight also showed significant activity in a dose dependent manner with $57.48 \%$ and $71.98 \%$ cell growth inhibition respectively (Figure 1).

\subsection{Average tumor weight and survival time}

In vivo tumor weight of EAC cell bearing mice after treatment with methanol extract of L.indica at the dose of $20 \mathrm{mg} / \mathrm{kg}, 30 \mathrm{mg} / \mathrm{kg}$ and 40 $\mathrm{mg} / \mathrm{kg}$ for 20 days was calculated. It was found that tumor weight decreases approximately in a similar manner with bleomycin $(0.3 \mathrm{mg} / \mathrm{kg})$. Highest tumor weight reduction (7.90g) was observed at the dose of $40 \mathrm{mg} / \mathrm{kg}$ (i.p) compared to the standard drug bleomycin (7.05g). Same extract at the dose of 20 and $30 \mathrm{mg} / \mathrm{kg}$ (i.p.) showed moderate reduction of tumor cell weight (Figure 2).

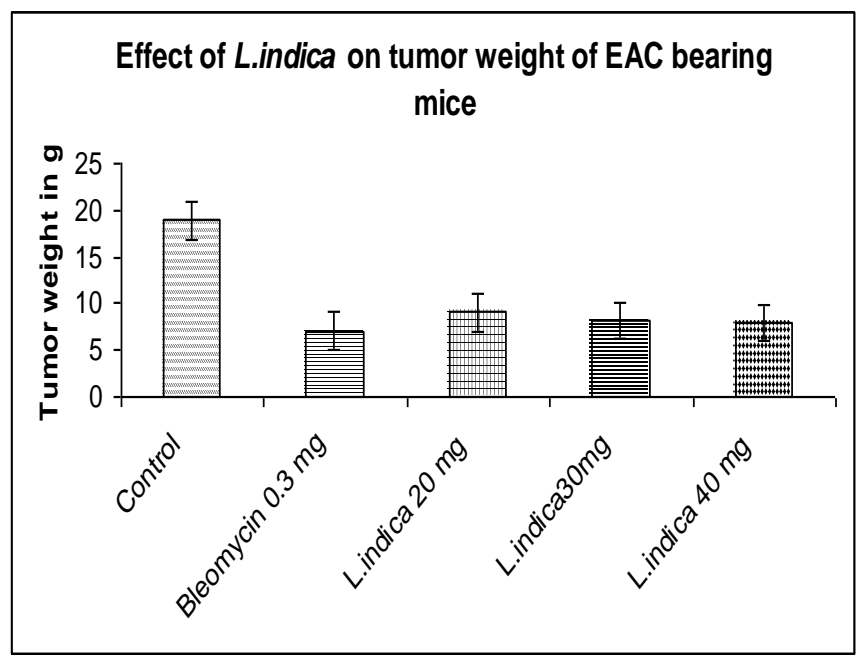

Figure 2. Effect of methanol extract of the leaves of L.indica on tumor weight of EAC cell bearing mice. Values are mean $\pm \operatorname{SEM},(n=5)$; where significant value is $* * \mathrm{p}<0.001$, Dunnet test as compared to control.

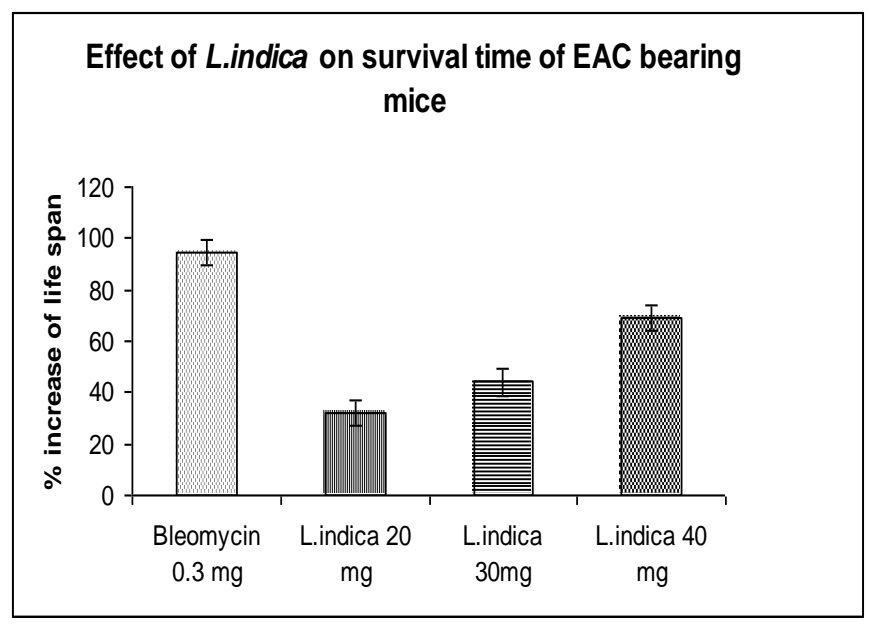

Figure 3. Effect of methanol extract of the leaves of L.indica on survival time of EAC cell bearing mice. Values are mean \pm SEM, $(n=5)$; where significant values are, ${ }^{*} \mathrm{p}<0.01$ and $* * \mathrm{p}<0.001$, Dunnet test as compared to control. 
Mean survival time (MST) of the untreated tumor bearing mice was 15 days. With the treatment of the three different doses of methanol extract of L.indica, this value increased remarkably. Maximum $69.33 \%$ enhancement of life span was found at the dose of $40 \mathrm{mg} / \mathrm{kg}$ (i.p.) whereas at the dose of $20 \mathrm{mg} / \mathrm{kg}$ (i.p) and $30 \mathrm{mg} / \mathrm{kg}$ (i.p.) the plant extract showed moderate effect- $32 \%$ and $44 \%$ respectively (Figure 3 ). Under the same experimental condition, bleomycin at the dose of $0.3 \mathrm{mg} / \mathrm{kg}$ (i.p.) increased the survival time to $94.66 \%(\mathrm{p}<0.01)$.

\section{DPPH scaveng ing activity of $L$.indic $a$}

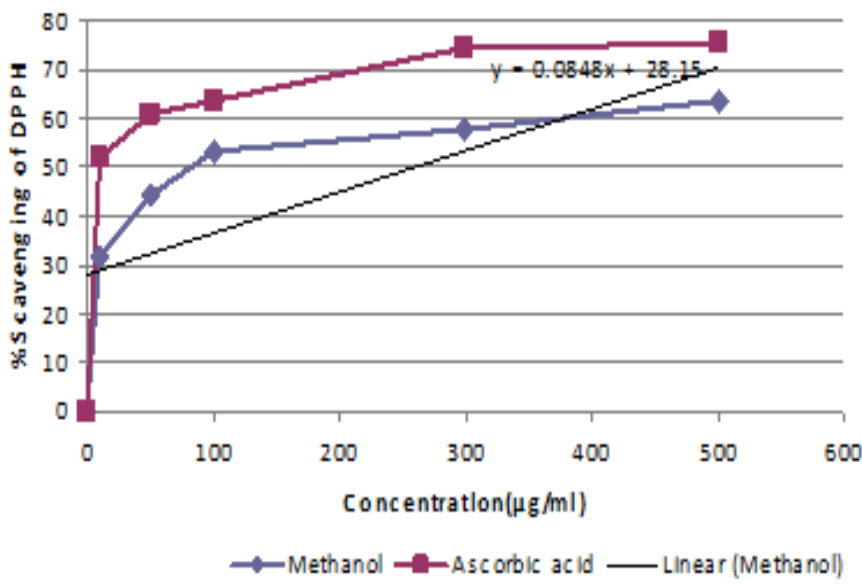

Figure 4. DPPH radical scavenging activity of methanol extract of the leaves of L.indica.

\subsection{DPPH radical scavenging activity}

The DPPH radical scavenging activity of L.indica is shown in Figure 4. This activity was found to increase with increasing concentration of the extracts. The DPPH radical contains an odd electron, which is responsible for the absorbance at $515-517 \mathrm{~nm}$ and also for a visible deep purple color. The $\mathrm{IC}_{50}$ value of the methanol extract was $257.66 \mu \mathrm{g} / \mathrm{ml}$ while the $\mathrm{IC}_{50}$ value of ascorbic acid was $11.24 \mu \mathrm{g} / \mathrm{ml}$.

\subsection{Total phenol and flavonoid content}

Table 1 shows the results of total phenol and flavonoid content of methanol extracts of the aerial parts of L.indica. The total phenol and total flavonoid content of the extracts were expressed in gallic acid and quercetin equivalents respectively. The content of phenolics in the extracts under this investigation correlates with the antioxidant activity; it showed moderate results $(120.88 \mathrm{mg} / \mathrm{g}$ GAE). Flavonoid content of the extract was also found significant $(150.14 \mathrm{mg} / \mathrm{g}$ quercetin equivalent).

Table 1. Total amount of phenol and flavonoid content of the leave extract of $L$.indica

\begin{tabular}{|l|l|l|}
\hline Extracts & $\begin{array}{l}\text { Total phenol } \\
\text { (In mg/g, } \\
\text { Gallic acid } \\
\text { Equivalents) }\end{array}$ & $\begin{array}{l}\text { Total flavonoid } \\
\text { (In mg/g, } \\
\text { Quercetin } \\
\text { Equivalents) }\end{array}$ \\
\hline $\begin{array}{l}\text { Methanol } \\
\text { extract of the } \\
\text { leaves of } \\
\text { L.indica }\end{array}$ & 120.88 & 150.14 \\
\hline
\end{tabular}

\subsection{Reducing power}

Figure 5 represent the reductive capabilities of the plant extracts compared to Ascorbic acid which was determined using the potassium ferricyanide reduction method. The reducing power of the extracts was moderately strong while increasing dose it showed remarkable increment.

\section{Reducing power activity of methan ol extract of $L$.} indica

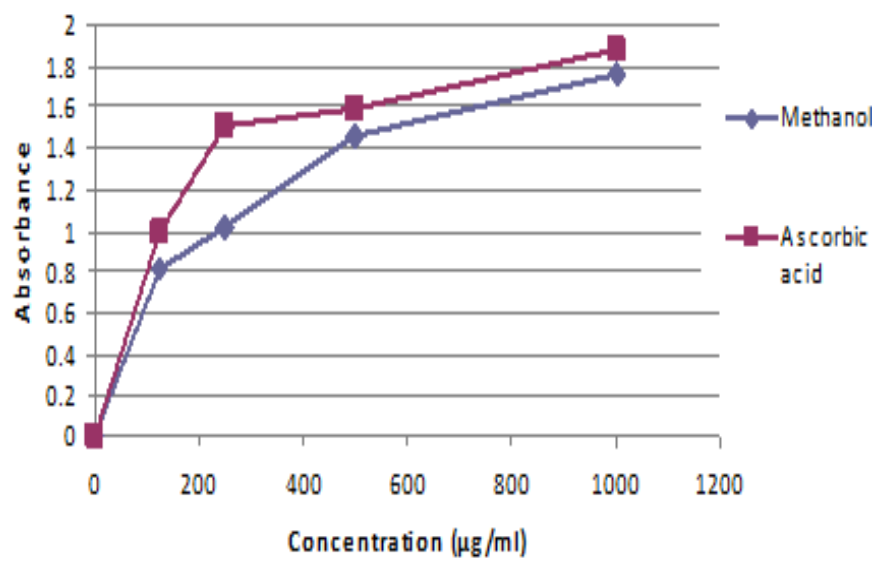

Figure 5. Reducing power activity of the methanol extracts of the leaves of L.indica and ascorbic acid. 


\subsection{Brine shrimp lethality bioassay $\left(\mathrm{LC}_{50}\right)$}

The brine shrimp lethality bioassay was done to assess the in vitro cytotoxic effect of the plant extract. Median lethal concentration $\left(\mathrm{LC}_{50}\right)$ of brine shrimp lethality was found to be $11.56 \mu \mathrm{g} / \mathrm{ml}$ (Figure 6).

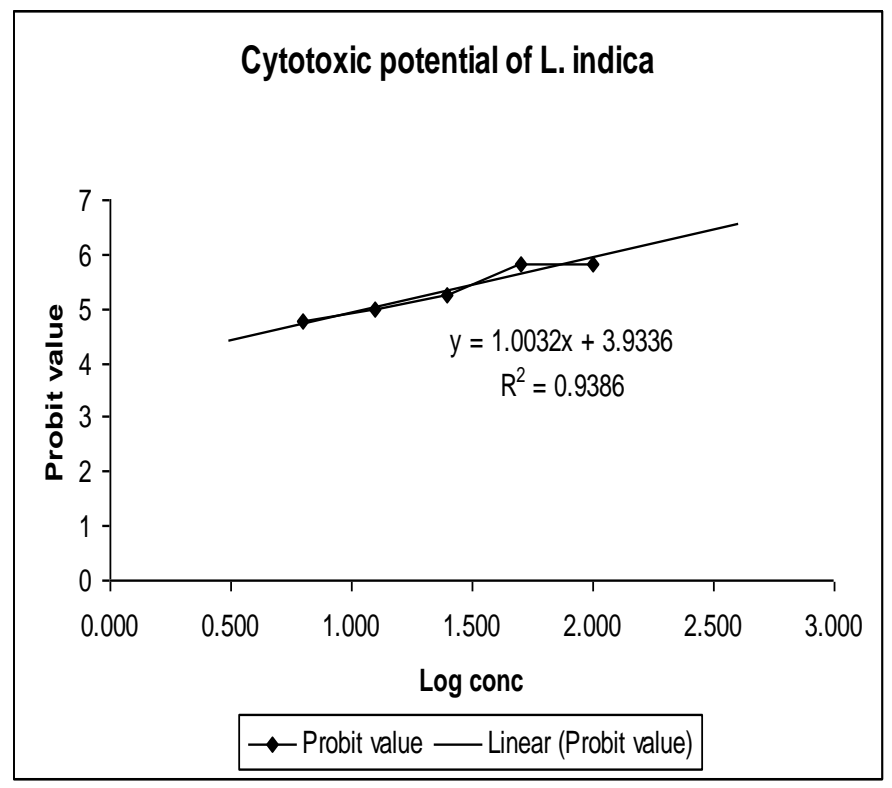

Figure 6: Effects of various log concentrations of methanolic extract of L.indica against brine shrimp nauplii after $24 \mathrm{hrs}$ of incubation.

\section{Discussion}

Experimental results presented above proved that the methanol extract of L.indica at its different doses (maximum effect observed at the dose of $40 \mathrm{mg} / \mathrm{kg}$ ) can slow down the growth of tumor satisfactorily, reduce tumor weight markedly and increase life span considerably. Our present study results also reflected that the same extract of L.indica showed moderate antioxidant and significant cytotoxic activity. All these are measured as very important aspects in justifying the effectiveness of a compound in cancer chemotherapy [28] Cancer is recognized primarily as a disease of uncontrolled cell division. Hence, all efforts are directed toward the identification of antiproliferative compounds. Accordingly, regression of tumor size and increase of survival time has been recognized as the primary objective end point of effectiveness in preclinical and clinical testing. Conventional screening models for anticancer agents are geared toward the selection of antioxidant and cytotoxic drugs. Antioxidants have been extensively studied for their ability to prevent cancer in human [29]. Several plant species rich in antioxidant flavonoids are reported to reduce disease risk and have therapeutic properties. Their consumption can reduce the risk of cancer [30,31]. Previous data also prove that flavonoids are biologically active against different strains of bacteria and many human cancer cell lines [32, 33, 34]. Moreover plant phenolics have drawn increasing attention due to their potent antioxidant properties and their marked effects in the prevention of various oxidative stress associated diseases such as cancer [35]. Remarkable cytotoxic activity shown by L.indica extracts can be attributed mainly to phenol, flavonoids and Gallic acid. Gallic acid is isolated from the leaves of L.indica [36] and active against several cancer cell lines [37]. Cytotoxic compounds triggers apoptosis through two signaling mechanisms - the activation and release of mitochondrial pro-apoptotic proteins known as caspases under the control of Bcl-2 family of proteins or up regulated expression of proapoptotic receptors on cancer cells, whose subsequent interaction with their ligands activates apoptotic signaling pathways. These receptors include the Fas (also called APO-1 or CD95) and the tumor necrosis factor (TNF)-related apoptosisinducing ligands (TRAIL) receptors. Numerous animal studies have been published demonstrating decreased tumor size and/or increased longevity with the combination of chemotherapy and antioxidants [38]. Antitumor activity recorded in the present study is in accordance with this finding, since the antioxidant and cytotoxic study indicated the presence of phenol, flavonoid and Gallic acid in the crude methanol extract of L.indica. Although most chemotherapeutic agents cause cellular damage by making lethal injury to DNA through initiating free radical oxidants; however, recent evidence indicates that a sizeable amount of chemotherapy damage is by other mechanism, for example radiation induced failure of mitosis and the inhibition of cellular proliferation, which kill cancer cells [39]. 
Moreover, apoptosis can be generated by the effect of radiation on cell membrane apparently through lipid peroxidation [40]. Resistance to many chemotherapeutic agents is thought to be due to reduced accumulation in tumor cell [41]. Recent research has focused on the ability of flavonoid type antioxidant compound to increase the concentration of chemotherapeutics in tumor cells. From literature review it was found that the methanol extract of the leaves of L.indica possess eleven hydrocarbons, phthalic acid, palmitic acid, 1-eicosanol, solanesol, farnesol, three phthalic acid esters, lupeol, _-sitosterol and ursolic acid in addition to gallic acid [42]. Though the results obtained from the antioxidant, cytotoxicity and antitumor activity study of this plant revealed that methanol extract of L.indica could be a rich source of anticancer drugs but still there is no consensus about which substances are exactly responsible for these effects. So, much more investigation including hematological studies have to be carried out with this extract using higher animal models, in order to confirm it as a potent anticancer drug resource.

\section{Acknowledgement}

The authors thank to Prof. Dr. Jahanara Khanom (Department of Biochemistry and Molecular Biology, University of Rajshahi, Bangladesh) for providing the EAC cells and also to Prof. Dr. Shaikh Bokhtear Uddin (Department of Botany, University of Chittagong, Bangladesh) for identification of the plant under investigation.

\section{References}

1. Cancer Research Campaign: Cancer in the European community. 1992, Fact sheet, 5.1.

2. Fabricant D. S., and Farnsworth N. R. The value of plant used in traditional medicine for drug discovery. Envir. Healt. Persp. 2001, v. 109, p. 69-75. DOI: 10.1289/ehp.01109s169.

3. Yoon Y., Kim Y. O., Jeon W. K., Park H. J., and Sung H. J. Tanshinone II A isolated from Salvia miltiorrhiza BUNGE induced apoptosis in HL60 human premyelocytic leukemia cell line. J. Ethnopharm. 1999, v. 68, p.121 - 7 . DOI: 10.1016/S0378-8741(99)00059-8.

4. Seo W. G., Pae H. O., Oh G. S., Chai K.Y., Yun Y. G., Chung H. T., Jang K. K., and Kwon T. O. Ethyl acetate extract of the stem bark of Cudrania tricuspidata induces apoptosis in human leukemia HL-60 cells. Am. J. Chin. Med. 2001, v. 29, p. $313-20$.

5. Lien H. M., Lin H. W., Wang Y. J., Chen L. C, Yang D. Y., Lai Y. Y., and Ho Y. S. Inhibition of Anchorage-Independent Proliferation and G0/G1 Cell-Cycle Regulation in Human Colorectal Carcinoma Cells by 4,7Dimethoxy-5-methyl-1,3-benzodioxole Isolated from the Fruiting Body of Antrodia camphorate. Evi. Comp. Alt. Med. 2009, v. 2011, p. 1-10. DOI:10.1093/ecam/nep020.

6. Bold R. J., Termuhlen P. M., and McConkey D. J. Apoptosis, cancer and cancer therapy. Surg. Oncol. 1997, v. 66, p. 133- 142. DOI: 10.1002/(SICI)1096 9098(199711)66:3<151

7. Wong Y. H., Kadir H. A., and Ling S. K. Bioassay-Guided Isolation of Cytotoxic Cycloartane Triterpenoid Glycosides from the Traditionally Used Medicinal Plant Leea indica. Evid. Comp. Alt. Med., 2012, v. 2012, p. 1-11. DOI:10.1155/2012/164689.

8. Lattif A. G., Omar I. M., Said I. M., and Kadri A. A multi-variate approach to the study of medicinal plants in Malaysia. J. Sing. Nat. Acad. Sci. 1980, v. 13, p. 101-113.

9. Chatterjee A., and Prakashi S. C. The Treatise on Indian Medicinal Plants. NISCAIR, New Delhi, India. 1994, v. 3, p. 173-174.

10. Prajapati N. D., Purohit S. S., Sharma A. K., and Kumar T. A Handbook of Medicinal Plants- A Complete Source Book. Agrobios. Jodhpur, India. 2003, p. 309-310.

11. Yusuf M., Wahab M.A., Chowdhury J.U., and Begum J. Some tribal medicinal plants of Chittagong Hill Tracts, Bangladesh. Bang. J. Plant. Taxon. 2007, v. 14, p.117-128.

12. Saha K., Lajis N. H., Israf D. A., Hamzah A. S, Khozirah S., Khamis S., and Syahida A. Evaluation of antioxidant and nitric oxide inhibitory activities of selected Malaysian medicinal plants. J. Ethnopharm. 2004, v. 92(2-3), p. 263-267. DOI:10.1016/j.jep.2004. $\underline{03.007 .}$. 
13. Raihan M. O., Habib M. R., Brishti A., Rahman M. M., Saleheen M. M., and Manna M. Sedative and anxiolytic effects of the methanolic extract of Leea indica (Burm. f.) Merr. Leaf. Drug Disc. \& Ther. 2011, v. 5, p. 185-189. DOI: 10.5582/ddt.2011.v5.4.185

14. Temkitthawon P., Viyoch J., Limpeanchob N., Pongamornkul W., Sirikul C., Kumpila A., Suwanborirux K., and Ingkaninan K. Screening for phosphodiesterase inhibitory activity of Thai medicinal plants. J. Ethnopharm. 2008, v.192, p. 214-217. DOI:10.1016/j.jep.2008.05.034.

15. Nurhanan M.Y., Asiah O., MohdIlham M. A., Siti Syarifah M. M., Norhayati I., and Lili S. H. Antiproliferative activities of 32 Malaysian plant species in breast cancer cell lines. J. Trop. For. Sci. 2008, v. 20, p. 77-81.

16. Wong Y. H., and Habsah A. K. Leea indica Ethyl Acetate Fraction Induces GrowthInhibitory Effect in Various Cancer Cell Lines and Apoptosis in Ca Ski Human Cervical Epidermoid Carcinoma Cells. Evid. Comp. Alt. Med. 2011, v. 2011, p. 0-13. DOI: 10.1155/2011/293060.

17. Litchfield J. T., and Wilcoxon F. A simplified method of evaluating dose-effect experiments. J. Pharmacol. Exp. Ther. 1949, v. 96, p. 99113. DOI: 10.1124/jpet.106.104463.

18. Sur P., and Ganguly D. K. Tea Plant Root Extract (TRE) as an Antineoplastic Agent. Planta. Med. 1994, v. 60, p. 106-109.

19. Abbot B. J. Bioassay of plant extracts for anticancer activity. Cancer Treatment Reports. 1976, v. 60, p. 1007-1017.

20. Hasan M. S., Ahmed M. I., Mondal S., Jamal Uddin S., Masud M. M., Sadhu S. K., and Ishibashi M. Antioxidant, antinociceptive activity and general toxicity study of Dendrophthoe falcata and isolation of quercetin as the major component. Orien. Pharm. Exp. Med. 2006, v. 6, p. 355-360.

21. Alam M. A. Antioxidant and hepatoprotective action of the crude methanolic extract of the flowering top of Rosa damascena. Orien. Pharm. Exp. Med. 2008, v. 8, p.164-170.

22. Singelton V. R., Orthifer R., and LamuelaRaventos R. M. Analysis of total phenols and other oxidation substrates and antioxidants by means of Folin-Ciocalteu reagent. Meth. Enzymol. 1999, v. 299, p.152-178. DOI: 10.1016/S0076-6879(99)99017-1.

23. Kumaran A., and Karunakaran A. J. In vitro antioxidant activities of methanol extracts of five Phyllanthus species from India. LWT Food. Sci. Tech. 2007, v. 40, p. 344-352. DOI: 10.1016/j.1wt.2005.09.011.

24. Oyaizu M. Studies on product of browning reaction prepared from glucose amine. Jap. J. Nutr. 1986, v. 44, p. 307-315.

25. Meyer B. N., Ferrigni N. R., Putnam J. E., Nichols D. E., and Mclaughlin J. L. Brine Shrimp: A convenient general bioassay for active constituents. Planta. Med. 1982, v. 45, p. 31-32.

26. Clarkson B. D., and Burichenal J. H. Preliminary screening of antineoplastic drugs. Prog. Clin. Can. 1965, v. 1, p. 625-629.

27. Jalalpure S. S., Patil M. B., Prakash N. S., Hemlata K., and Manvi F. V. Hepatoprotective activity of fruits of Piper Longum Linn. Ind. J. Pharm. Sci. 2003, v. 65, p. 360-366.

28. Price V. E., and Greenfield R. E. Anemia in cancer. Adv. Can. Res. 1958, v. 5, p. 199-200..

29. Singh D. K., and Lippman S. M. Cancer chemoprevention part 1: Retinoids and carotenoids and other classic antioxidants. Oncol. 1998, v.12, p. 1643-1660.

30. Ferguson P. J., Kurowska E., Freeman D. J., Chambers A. F., and Koropatnick D. J. A flavonoid fraction from cranberry extract inhibits proliferation of human tumor cell lines. J. Nutr. 2004, v. 134, p.1529-1535. DOI: 10.1021/bk-2010-1035.ch012.

31. Kanadaswami C., Lee L., Lee P. H., Hwang J., Ke F., Huang Y., and Lee M. The antitumor activities of flavonoids .In Vivo. 2005, v.19, p. 895-909.

32. Havsteen B. H. The biochemistry and medical significance of the flavonoids. Pharmacol. Therap. 2002, v., 96, P. 67-202.

33. Mahato S. B., Nandy A. K., and Roy G. Triterpenoids. Phytochem. 1992, v. 31, p. 2199-2249. DOI: 10.1016/0031-9422(92) 83257-Y.

34. Min, B. S., Gao J. J., Nakamura N., and Hattori M. Triterpenes from the spores of Ganoderma lucidum and their cytotoxicity 
against meth-A and LLC tumor cells. Chem. Pharm. Bull. 2000, v. 48, p. 1026-1033.

35. Jin D., and Russell J. M. Plant Phenolics: Extraction, Analysis and Their Antioxidant and Anticancer Properties. Molecules. 2010, v.15, p. 7313-7352. DOI: 10.3390/molecules15107313.

36. Srinivasan G. V., Ranjith C., and Vijayan K. $\mathrm{K}$. Identification of chemical compounds from the leaves of Leea indica. Acta Pharm. 2008, v. 58, p. 207-214. DOI: 10.2478/v1007-008$\underline{0002-7 .}$.

37. Wansu P., Mun S. C., Hocheol K., Ho Y. C., Woong M. Y., Do R. K., Eun H. P., and Seong K. P. Cytotoxic effect of gallic acid on testicular cell lines with increasing $\mathrm{H}_{2} \mathrm{O}_{2}$ level in GC-1 spg cells. Tox. in Vitro. 2008, v. 22, p. 159-163. DOI:10.1016/j.tiv.2007.08.010.

38. Chinery R., Brockman J. A., Peeler M. O., Shyr Y., Beauchamp R. D., and Coffey R. J. Antioxidant enhances the cytotoxicity of chemotherapeutic agents in colorectal cancer: a p53-independent induction p21 via C/EBP-beta. Nat. Med. 1997, v. 3, p.12331241. DOI: $10.1038 / \mathrm{nm} 1197-1233$.

39. Schmitt C. A., and Lowe S. W. Apoptosis and therapy. J. Path.1999, v. 187, p. 127-137.

40. Holland J. F., and Bast R. C. Cancer Medicine. MD: Williams and Wilkins. Baltimore, USA. 1997, v. 1, 4th eds, p. 261-276.

41. Robert J. Multi drug resistance in oncology: Diagnostic and therapeutics approaches. Eur. J. Clin. Invest. 1999, v. 29, p. 536-545. DOI: 10.1046/j.1365-2362.1999.00495.x

42. Srinivasan G. V., Vijayan K. K., Sharanappa P., and Leela N. K. Chemical composition and anti microbial activity of the essential oil of Leea indica (Burm.f) Merr.flowers. Nat. Prod. Rad. 2009, v. 8, p. 488-493. 